\title{
A hatékony védelemhez való jog az Emberi Jogok Európai Bíróságának joggyakorlatában ${ }^{1}$
}

\section{GÁCSI Anett Erzsébet ${ }^{2}$}

\begin{abstract}
A tágabb és szükebb értelemben kategorizálható fegyverek egyenlösége elv a tisztességes eljáráshoz való jog lényegi eleme, amely a büntetőeljárásban azt garantálja, hogy a védelemnek (terhelt és védő) a váddal összevethető súlyú jogosítványai legyenek. A védelemhez való jog (az EJEB joggyakorlatában, valamint több külföldi, valamint az új magyar büntetőeljárási törvényben: hatékony védelemhez való jog) a tisztességes eljáráshoz való jognak nevesített eleme, a fegyverek egyenlösége elvnek pedig tágabb értelemben szintén egyik alkotóeleme (szúkebb értelemben azon kívül esik, azonban több kapcsolódási pontjuk van). Tanulmányomban a hatékony védelemhez való jog tartalmát az EJEB joggyakorlatán keresztül mutatom be.
\end{abstract}

Kulcsszavak: alapelvek, tisztességes eljáráshoz való jog, hatékony védelemhez való jog, fegyverek egyenlöségének elve

A büntető eljárásjog tudományának mai felfogása szerint alapelvek nélküli eljárás nem képzelhető el, ugyanakkor tény, hogy az alapelvek jelentőségének felismerése és azok rendszerezése, a róluk szóló tanok kidolgozása viszonylag késői fejlemény a büntető eljárásjog tudományában. ${ }^{3} \mathrm{~A}$ tanulmányom középpontjában álló védelemhez való jog a vegyes büntetőeljárási rendszerek egyik sarokköve, alapelve, amelyet deklarál az emberi jogok és alapvető szabadságok védelméről szóló, Rómában 1950. november 4-én kelt egyezmény (a továbbiakban: egyezmény vagy EJEE) is [6. cikk 3. bekezdés c) pont]. Az egyezmény azonban csak a legalapvetőbb jogelveket tartalmazza, így azok tartalmát az Emberi Jogok Európai Bírósága (a továbbiakban: bíróság vagy EJEB) tölti ki tartalommal.

Felmerül a kérdés, hogy miért lehet indokolt vizsgálni az EJEB joggyakorlatát. Kiindulópontom az, hogy strasbourgi döntések egyedi ügyekben születnek, és általános kötelező erővel nem rendelkeznek. ${ }^{4}$ Ugyanakkor az egyezmény és a hozzá kapcsolódó bírósági

\footnotetext{
A tanulmány Az Emberi Erőforrások Minisztériuma UNKP-17-4 kódszámú Új Nemzeti Kiválóság Programjának támogatásával készült.

2 GÁCSI Anett Erzsébet dr., PhD, egyetemi adjunktus, SZTE Állam- és Jogtudományi Kar, Bünügyi Tudományok Intézete

Anett Erzsébet GÁCSI dr., PhD, Senior Lecturer, SZTE Faculty of Law and Political Sciences, Institute of Criminal Law and Criminal Science

orcid.org/0000-0003-3455-4629, dr.gacsianettgmail.com

3 Erdei (2011) 123.

4 Szabó (2017) 128.
} 
gyakorlat az alapjogvédelemnek azt a minimumszintjét határozza meg, amelyet minden részes államnak biztosítania kell, hozzátéve azt, hogy a nemzeti jog azonban ettől eltérő, magasabb követelményrendszert is kialakíthat az emberi jogok védelmére. ${ }^{5}$

A fenti megállapításokat a magyar jogrendszerre vetítve: a bíróság döntései tehát zsinórmértékül szolgálnak a magyar jogban is. Ennek vissza kell tükröződnie a jogalkotásban és a jogalkalmazásban egyaránt. Utóbbi kapcsán a magyar rendes bírósági gyakorlatot tekintve megállapítható, hogy a strasbourgi esetjog egyre inkább megjelenik a bíróságok ítéleteiben és a felsőbb bíróságok útmutatásaiban, ${ }^{6}$ ugyanakkor a számos pozitív példa ellenére az EJEB-konform értelmezés követelménye a rendes bíróságok gyakorlatában közismerten nehezen honosodik meg. ${ }^{7}$ („Ékes példaként” szolgálhat az utóbbira az előzetes letartóztatással kapcsolatos - elsősorban a védelem oldalát érintő - iratmegismeréssel összefüggő szempontok érvényesítésével kapcsolatban felmerülő hazai nehézségek.) ${ }^{8}$

Jelen tanulmány célja egyfelől a (hatékony) védelemhez való jog EJEB joggyakorlatán keresztül történő bemutatása [így 1. rendszertani elhelyezése; 2. a jogot deklaráló egyezmény 6. cikk 3. bekezdés c) pontjának grammatikai értelmezése; 3. a „hatékony” jelző szükségességének és jelentésének vizsgálata; 4 . a védelem hatékonysági síkjainak feltérképezése]; másfelől a megfogalmazott minimum követelmények magyar büntetőeljárásokban való adaptálási lehetőségeinek vizsgálata. Utóbbi kifejezetten indokolt, hiszen 2018. július 1-jétől részint struktúrájában (így a nyomozást eshetőlegesen megelőző előkészítő eljárás bevezetésével, a tárgyalás előkészítésének hangsúlyosabbá tételével), részint szemléletében (így a terhelti együttmúködés komplex rendszerének megteremtésével és a büntetőeljárások központi kérdésének tételével) megváltozott új büntetőeljárási kódex lép hatályba, amelyben az egyik alapvető eljárási funkció, a védelem, még inkább megköveteli az EJEB által lefektetett minimumkövetelmények biztosítását.

\section{Rendszertani elhelyezés}

A védelemhez való jog a tisztességes eljáráshoz való jognak explicite nevesített eleme, az egyezmény a 6. cikk 3 . bekezdés c) pontjában deklarálja azt (szorosabb értelemben vett védelemhez való jog). E ponton kiemelést érdemel, hogy a magyar Alaptörvény is e struktúrában értelmezi a védelemhez való jogot [XXVIII. cikk (3) bekezdés]; az új magyar büntetőeljárási törvény [2017. évi XC. törvény a büntetőeljárásról (a továbbiakban: Be.)] pedig múködési alapelvként nevesíti (3. §), mitöbb hatékony védelemhez való jog formájában jelöli azt meg [3. § (1) bek.]. Ugyanakkor az új Be. - mint a jogszabály

\footnotetext{
Kimondja például: 4/2013. (II. 21.) AB határozat, ABH 2013, 128, 19. pont; Vö. Szabó (2017) 128-129.

Uitz (2016) 200.

Kovács (2013) 159-160.

A magyar szakirodalom e problémakör vizsgálatára kiemelt figyelmet fordított, így például (a szerző önkényes válogatása alapján): Elek (2015) 78-94.; Kádár et al. (2014); Róth (2016) 56-74.; Szabó (2016) 183-188.
} 
normatív tartalommal nem rendelkező logikai egységében ${ }^{9}$ - a preambulumban vezérelvként megfogalmazza a tisztességes eljáráshoz való jogot, utalva arra, hogy a jelzett ünnepélyes hangvételű bevezetőben megfogalmazott elvek a tételes törvényi rendelkezések értelmezését orientálják; ${ }^{10}$ azaz a védelemhez való jog így (az EJEE és az Alaptörvény mellett) értelmezhető a tisztességes eljáráshoz való jog szerves részeként.

Megjegyzendő azonban a rendszertani elhelyezéssel kapcsolatban egyfelől az, hogy a védelemhez való jog az egyezmény 6. cikk 3. bekezdés a) (tájékoztatás a vádról a terhelt által értett nyelven) ${ }^{11}$ és b) (a védekezés előkészítése) ${ }^{12}$ pontjaival is szoros összefüggésben áll, e pontok is a védelemhez való jog szabályainak minősülnek (tágabb értelemben vett védelemhez való jog). Ugyanakkor a bírósági joggyakorlat szerint az egyezmény 6. cikkének ezen pontjai viszonylag ritkán eredményeznek egyezménysértést. [Egyebekben a 6. cikk 3. bekezdés a) és b) pontjai szervesen összefüggnek: vagyis az a) pont alapján nyújtott információknak a b) pont elvárásaihoz is igazodniuk kell. ${ }^{13}$ ]

Másfelől a hatékony védelemhez való jog szoros összefüggést mutat az egyezménybe implicite beleértett fegyverek egyenlősége [a francia doktrína szerint ügyfélegyenlőség) elvével is (egyezmény 6. cikk 3. bekezdés d) pont]. ${ }^{14}$ Hazánkban erre az összefüggésre a 20. század elején - negatív irányú megközelitéssel - Balogh Jenő is rámutatott: „Akármennyit hangoztatják is az elméleti szakférfiak az ügyfélegyenlőségnek kívánatos voltát, bizonyos, hogy korunknak állami közvádlójával és a védelemnek ez idő szerinti szervezete mellett ez az egyenlőség a gyakorlatban, a dolog lényegét tekintve egyáltalában nem érhető el." ${ }^{15}$ Álláspontom szerint - úgynevezett pozitív irányú megközelítés - valódi kapcsolat mutatható ki a fegyveregyenlőség elve és a védelemhez való jog között. Ennek a megközelítésnek a kiindulópontja az EJEB joggyakorlata, valójában az, hogy a bíróság a fegyverek egyenlőségének elvét tágabb és szúkebb értelemben határozza meg. Szúkebb értelemben csak az egyezmény 6. cikk 3. bekezdés d) pontjában megjelenő tanúkihallgatást (konfrontáció) érti az elv alatt; tágabb értelemben ugyanak-

\footnotetext{
Vö. 61/2009. (XII. 14.) IRM rendelet a jogszabályszerkesztésről, 51. §.

Erdei (2018) 25-26.

11 Következetes egyfelől a bíróság abban, hogy a tájékoztatásnak ténylegesen meg kell történnie, annak valószínűsítése, hogy az információ (a vád) a terhelthez eljutott, nem elegendő. Másfelől követelmény az, hogy a tájékoztatás a lehető legrövidebb időn belül (a bíróság szóhasználata szerint haladéktalanul) megtörténjen. Kamasinski v. Austria, Judgment of 19 December 1989, Series A no. 168.; Steel and Others v. the United Kingdom, Judgment of 23 September, 1998, Reports-VII., 2719; Borisova v. Bulgaria (Application no. 5689/00) Judgment of 21 December 2006.

12 E ponttal kapcsolatban többségében az a körülmény alapozza meg az egyezménysértést, hogy a vád tárgyává tett cselekmény megváltozásáról a bíróság nem értesíti a terheltet, arról később, a jogorvoslati eljárásban szerez csak tudomást a védelem oldala. Például: Pélissier and Sassi v. France (Application no. 25444/94) Judgment of 25 March 1999. A jelzett ítélet volt az alapja a hazánkat e tárgykörben érintő Dallos-ügynek is [Dallos v. Hungary (Application no. 29082/95) Judgment of 1 March 2001]. Lásd továbbá: Sadak v. Others v. Turkey (Application nos 29900/96, 29901/96, 29902/96, 29903/96) Judgment of 17 July 2001; Mattei v. France (Application no. 34043) Judgment of 19 December 2006; Miraux v. France (Application no: 73529/01) Judgment of 26 September 2006; I.H. and Others v. Austria (Application no. 42780/98) Judgment of 20 April 2006. A bíróság az e pontban rögzített követelmények esetleges sérelmét egyebekben a védelem egészéhez viszonyítva vizsgálja.

13 Grád-Weller (2011) 392.

14 Az elnevezési dilemmához lásd: Gácsi (2017a) 90-93.

15 Balogh (1901) 317. Megjegyzést érdemel, hogy Balogh Jenő az ügyfélegyenlőség elvét következetesen tagadta a büntetőeljárásban, innen ered a negatív irányú megközelítés.
} 
kor a 6. cikk 1. bekezdése is a fegyveregyenlőség elvét jelentheti az alábbi klasszifikáció szerint. Egyfelől az egyezmény 6. cikk 1. bekezdését megvalósító azon indok alapján, hogy a 6. cikk 1. pontja szubszidiárius jellegú klauzula, azaz, ha nincs olyan specifikus a 6. cikk 3. bekezdés d) pontjában nevesített körülmény, elem, amely alapján az ügyet vizsgálni lehetne, meg lehet állapítani az egyezménysértést (és így a fegyverek egyenlősége elv sérelmét). Másfelől az egyezmény 6. cikk 1. bekezdését megvalósító azon indok alapján, hogy az eset komplex, a 6. cikk 2. és 3. bekezdését (esetleg annak több pontját) is érinti. Utóbbi alcsoport esetén további feltétel, hogy az egyes pontok önmagukban még nem lennének alkalmasak a 6. cikk sérelmének megállapításához, összességükben azonban az egyezménysértés (így a fegyverek egyenlőségének sérelme megállapítható). ${ }^{16}$ A fentiekből látható, hogy a bíróság értelmezésében a védelemhez való jog a tágabb értelemben vett fegyverek egyenlösége elv egyik alkotóeleme. (Szűkebb értelemben azon kívül esik, azonban több kapcsolódási pontjuk van. ${ }^{17}$ )

E ponton felmerül a kérdés, hogy a 6. cikk 3. bekezdés c) pontjában szabályozott védelemhez való jog önállóan értelmezhetô-e, avagy az eszköz-cél relációban az csak a 6. cikk 1. bekezdésében deklarált tisztességes eljáráshoz való joggal „együttolvasva" értelmezhető. ${ }^{18} \mathrm{~A}$ bíróságnak e tekintetben hullámzó a joggyakorlata. Az EJEB ugyanis a 2008-ig azt a megközelítést alkalmazta, hogy a 6. cikk 3. bekezdés c) pontjának megsértését nem önállóan, hanem a 6. cikk 1. bekezdéssel együtt olvasva állapította meg. ${ }^{19} \mathrm{Ez}$ pedig azt jelentette, hogy a 6. cikk 3. bekezdés c) pontjának sérelmét akkor nem állapította meg, ha úgy találta, hogy noha a 6. cikk 3. bekezdés c) pontjában foglaltakat nem tartották be a nemzeti hatóságok, ugyanakkor a tárgyalás egészében nézve tisztességes volt. ${ }^{20}$ 2008-ban a Salduz v. Törökország ügyben fordulópont következett be: a bíróság a döntésével ugyanis megteremtette a védelemhez való jog önállósítását azzal, hogy - ha vizsgálta is a bíróság a 6. cikk 1. bekezdésének sérelmét - a 6 . cikk 3 . bekezdés c) pont önállóan alkalmazhatóságát mondta ki. ${ }^{21}$ A nemzetközi szakirodalom szerint a védelemhez való jog független státusza ebben az ügyben azáltal lett megteremtve, hogy a bíróság a védelemhez való jogot az első gyanúsítotti kihallgatás időpontjához kötötte. ${ }^{22}$ Később a Salduz-ügyben megfogalmazottakat pontosította a bíróság, így például 2009-ben a Dayanan-ügyben már

\footnotetext{
A szűkebb és tágabb fegyveregyenlőség tartalmi elemeihez lásd: Gácsi (2017b) 10-18.

7 Lásd részleteiben: Gácsi (2017b) 10-16.

8 Reid (2015) 188.

9 Vö. Kézikönyv a büntetőeljárások terheltjeinek védöhöz és költségmentességhez való jogáról (2018) 9-10.

20 Iskolapéldái ennek a Sarikaya v. Turkey (Application no. 36115/97) Judgment of 22 April 2004; valamint a Mamac and Others v. Turkey (Application nos. 29484/95, 29487/95, 29853/96) Judgment of 20 April 2004.

21 Salduz v. Turkey (Appication no. 36391/02) Judgment of 27 November 2008; ezt erősítették még az alábbi döntések: Pischalnikov v. Russia (Application no. 7025/04) Judgment of 24 September 2009; Laska and Lika v. Albania (Application nos. 12315/04, 17605/04), Judgment of 20 April 2010; Leonid Lazarenko v. Ukraine (Application no. 22313/04) Judgment of 28 October 2010; Nechiporuk and Yonkalo v. Ukraine (Application no. 42310/04) Judgment of 21 April 2011; Nechto v. Russia (Application no. 24893/05), Judgment of 24 January 2012; Todorov v. Ukraine (Application no. 16717/05) Judgment of 12 January 2012; Gonta v. Romania (Application no. 38494/04) Judgment of 1 October 2013; A. T. v. Luxemburg (Application no. 30460/13) Judgment of 9 April 2014; Turbylev v. Russia (Application no. 4722/09) Judgment of 6 October 2015; Borg v. Malta (Application no. 37537/13) Judgment of 12 January 2016.

22 Lemmens (2014) 312.
} 
az ôrizetbe vételtôl kezdve megillető jogosultságként aposztrofálta a védelemhez való jog intézményét. ${ }^{23} 2009$ után azonban következetlen bírósági joggyakorlat mutatható ki e kérdésben: a bíróság hol a Salduz- és Dayanan-ügyben lefektetett „szabályokat” (védelemhez való jog önállósítása) követi, hol a 2008 előtti értelmezéséhez hasonló döntéseket hoz. ${ }^{24}$ Legutóbb például a 2017-ben meghozott Simeonovi-ügyben egyértelmúvé tette a bíróság, hogy „a védelemhez való jogot az eljárás egészében vett tisztességességének rendeli alá”, azaz döntésében azt a Salduz-ügy előtti esetjogot hozta vissza, amelyben a védelemhez való jog önállóságát (az egyezménysértés szempontjából) nem ismeri el. Nem osztom a bíróság fenti érvelését, álláspontom szerint az védelemhez való jog mint emberi jog vonatkozásában visszalépést hozott. Nem érthető továbbá abból a szempontból sem az EJEB döntése, hogy pont a Salduz-döntés hatására a védelemhez való jog önállósítása tükröződik vissza a Stockholmi Program keretében elfogadott 2013/48 EU és a 2016/1919 EU irányelvekben is. ${ }^{25}$

Végezetül megjegyzést érdemel a rendszertani elhelyezéssel kapcsolatban, hogy a bíróság értelmezésében a védelemhez való jog az egyezmény 5. cikkének (Szabadsághoz és biztonsághoz való jog), 8. cikkének (Magán- és családi élet tiszteletben tartásához való jog), valamint a 10. cikkének (Véleménynyilvánítás szabadsága) érvényesülése szempontjából is vizsgálandó, e vizsgálatot azonban terjedelmi korlátok miatt jelen tanulmány keretei között nem végezhetem el. ${ }^{26}$

\section{Az EJEE 6. cikk 3. bekezdés c) pontjának megszövegezési kritikája}

A védelem jogát tartalmazó 6 . cikk 3. bekezdés c) pontja a magyar fordítás szerint a következőképp hangzik: „Minden bűncselekménnyel gyanúsított személynek joga van - legalább - arra, hogy személyesen, vagy az általa választott védő segítségével védekezhessék, és ha nem állnak rendelkezésére eszközök védő díjazására, amennyiben az igazságszolgáltatás érdekei ezt követelik meg, hivatalból és ingyenesen rendeljenek ki számára ügyvédet." Hasonló megfogalmazással él a francia nyelvú szöveg is, azaz a tagmondatot („ha nem állnak rendelkezésére eszközök védő díjazására”) „és” kötőszóval kezdi. ${ }^{27}$ Ugyanakkor az angol nyelvü szöveg a jelzett tagmondat határnál a „vagy”

\footnotetext{
Dayanan v. Turkey (Application no. 7377/03) Judgment of 13 October 2009; Cape et al. (2010) 32.

4 Vö. Kézikönyv a büntetôeljárások terheltjeinek védőhöz és költségmentességhez való jogáról (2018) 11-12.

25 „Az Európai Parlament és a Tanács 2013/48/EU irányelve (2013. október 22.) a büntetőeljárás során és az európai elfogatóparancshoz kapcsolódó eljárásokban ügyvédi segítség igénybevételéhez való jogról, valamint valamely harmadik félnek a szabadságelvonáskor történő tájékoztatásához való jogról és a szabadságelvonás ideje alatt harmadik felekkel és a konzuli hatóságokkal való kommunikációhoz való jogról”; továbbá „Az Európai Parlament és a Tanács (EU) 2016/1919 irányelve (2016. október 26.) a büntetőeljárások során a gyanúsítottak és a vádlottak, valamint az európai elfogatóparancshoz kapcsolódó eljárásokban a keresett személyek költségmentességéről”.

26 A vizsgálathoz lásd: Cape et al. (2010) 6.

27 „Tout accusé a droit notamment à se défendre lui-même ou avoir l'assistance d'un défenseur de son choix et, s'il n'a pas les moyens de rémunérer un défenseur, pouvoir être assisté gratuitement par un avocat d'office, lorsque les intérêts de la justice l'exigent."
} 
kötőszót használja. ${ }^{28}$ Tekintettel arra, hogy az egyezményt értelmező bíróság hivatalos munkanyelve az angol és a francia, ${ }^{29}$ az egyezmény angol és francia változatában megjelenő eltérő kötőszóhasználat eltérő értelmezési lehetőségeket rejt magában. A bíróság észlelve ezt, 1983-ban a Pakelli v. Németország határozatában kinyilvánította azt, hogy a 6. cikk 3. bekezdés c) pontját úgy kell értelmezni, hogy „az érintetteknek megfelelő anyagi eszközök hiányában joga van az ingyenes jogi képviseletre, amennyiben az igazságszolgáltatás érdekei ezt megkívánják”. ${ }^{30}$

A 6. cikk 3. bekezdés c) pontjának megszövegezése kapcsán másik problémát vethet fel, hogy az „igazságszolgáltatás érdeke” nehezen meghatározható (nem egzakt) fogalom. ${ }^{31}$ A bíróság esetjogát vizsgáló szakirodalom szerint a fogalomhoz a következőket kell vizsgálni: (i) az érintett oldalán a büntetőeljárásból fakadó kockázatot; (ii) a büntetőeljárás jellegét; (iii) a várható joghátrány súlyát; (iv) a terhelt képességét (és lehetőségeit) arra, hogy saját magát védje. ${ }^{32}$

\section{A hatékony jelző (megjelenése) a védelemhez való jog kapcsán}

A hatékony jelzőt a védelemhez való jog kapcsán az Artico v. Olaszország ügyben használta először a bíróság. ${ }^{33} \mathrm{~A}$ magyar büntetőeljárásokban is komoly problémát jelentő kirendelt védői rendszer kapcsán fejtette ki ugyanis az EJEB az álláspontját, miszerint önmagában a védő kirendelésével a terhelt nem kap hatékony védelmet (a védő kirendelése ugyanis csupán formalitás, de nem tényleges és hatékony védelem biztosítása) ${ }^{34}$. $\mathrm{Az}$ alapügyben az olasz bíróság ugyan rendelt ki védőt a terheltnek, az azonban más elfoglaltságaira tekintettel érdemben soha nem járt el az ügyben, és a terhelt ismételt kérelmei ellenére nem rendelt ki számára a bíróság másik védőt. A bíróság szerint azzal, hogy a tagállami hatóság eltűrte a kirendelt védő mulasztását, egyezménysértés valósult meg. ${ }^{35}$ Azóta további számos ügyben vizsgálta és alakította az EJEB a hatékony védelemhez való jog tartalmát. ${ }^{36}$

E ponton az is megjegyzést érdemel, hogy az EJEB joggyakorlata alapján a magyar Alkotmánybíróság is úgy foglalt állást, hogy a büntetőeljárással szemben követelmény, hogy a terhelt védelemhez való joga hatékonyan érvényesüljön. ${ }^{37}$

\footnotetext{
28 „Everyone charged with a criminal offence has the following minimum rights to defend himself in person or through legal assistance of his own choosing, or if he has not sufficient means to pay for legal assistance, to be given it free when the interests of justice so require."

29 Grád-Weller (2011) 21.

30 Pakelli v. Germany Judgment of 25 April 1983, Series A no. 64.

31 Grád-Weller (2011) 400.

2 Grád-Weller (2011) 400.

33 Artico v. Italy, Judgment of 13 May 1980, Series A no. 37.

34 Vö. Sakhnovskiy v. Russia (Application no. 21272/03) Judgment of 5 February 2009.

35 Vö. Grád-Weller (2011) 405.

36 Így például: Goddi v. Italy, Judgment of 9 April 1984, Series A no. 76; Alimena v. Italy, Judgment of 19 February 1991, Series A no. 195-D; Imbrioscia v. Switzerland, Judgment of 24 November 1993, Series A no. 275.; Daud v. Portugalia, Judgment of 21 April 1998, Reports 1998-II. 739.; Czekella v. Portugal (Application no. 38830/97) Judgment of 10 October 2002; Bogumil v. Portugal (Application no. 35228/03) Judgment of 7 October 2008.

37 8/2013. (III. 1.) AB, ABH 2013, 312, 322 [27. pont].
} 
Noha már átvezet tartalmi kérdéshez, ugyanakkor e ponton tartom szükségesnek megjegyezni azt, hogy álláspontom szerint a hatékony védelemhez való jog egy hárompólusú jogviszonyt foglal magában. A terhelt oldalán jogként (1. elem), a bűnügyi hatóságok részéről kötelezettségként (2. elem), míg a védők vonatkozásában jogként és kötelezettségként (3. elem) realizálódik. Az 1. elem sem az EJEB, sem a magyar joggyakorlat vonatkozásában nem volt vitatott, amióta a vegyes büntetőeljárási rendszerekről beszélünk [a magyar büntető perjogban 1900. január 1-jén lépett hatályba a vegyes rendszert követő első írott Bűnvádi Perrendtartási kódex (1896. évi XXXIII. tc.), azóta a terheltet a büntetőeljárás alanyaként megilleti a védelem joga]. A 2. elem az EJEB joggyakorlatában kiemelt kérdéskör, pont az Artico-ügyben rendelkezett úgy a bíróság, hogy „alapjaiban az államnak (a hatóságoknak) kell gondoskodnia a hatékony védelemről”. A magyar büntetőeljárásjog is elismeri ezt a kötelezettséget a tételes szabályai között [Be. 3. § (3) bek.]. A 3. elem az EJEB joggyakorlatában a 2. elemmel együtt párhuzamosan elismert pólus (nem vitatva, hogy a bíróság is a kirendelt védők vonatkozásában hangsúlyozza annak fontosságát), a magyar büntető eljárásjogban azonban azóta van kiemelt jelentősége, amióta a védőt a büntetőeljárás önálló főszemélyének tekintik (1962. évi 8 tvr.). ${ }^{38} \mathrm{Az}$ új Be. széles körű jogokat biztosít a védőnek [így például külön kitér a magánnyomozás kérdéskörére - Be. 42. § (2) bek. c) pont], ugyanakkor a hatékony védelemhez való jog érvényesülése miatt a védő kötelezettségeinek a körét is tételesen meghatározza [Be. 42. § (4) bek.]. A törvényindokolás ettől tovább megy, és a hatékony jelző bevezetését a (kirendelt) védők felé jelzett plusz elvárásként fogalmazza meg - utalva a kirendelt védői rendszer jelenlegi problémáira. ${ }^{39}$

Álláspontom szerint az is a hatékony védelemhez való jog egyik alapköve, hogy a terheltnek a védelmet - ahogyan arra a bíróság több határozatában rámutatott ${ }^{40}-a$ büntetöeljárás kezdetétöl biztosítani kell.

\section{A védelem hatékonyságának síkjai, ${ }^{41}$ avagy a hatékony védelemhez való jog tartalma}

Az, hogy mi eredményezhet egyezménysértést a hatékony védelemhez való jog kapcsán, a hatékony védelemhez való jog tartalmi elemei oldaláról válaszolható meg. A válasz azonban korántsem egzakt, a jog tartalma ugyanis a Bíróság esetjoga alapján változik, néhol evolucionista, néhol pedig revolucionista irányban. A legfőbb tartalmi elemek az alábbiakban foglalhatók össze. ${ }^{42}$

Egyfelől a védelem jogának gyakorlása oldaláról beszélhetünk 1. személyes (érdemi) védekezésről, azaz amikor a terhelt (is) gyakorolja saját védelmének ellátását; 2 . formá-

\footnotetext{
38 Vö. Bánáti (2018) 103.

39 Indokolás (2017) 3. §.

40 Murray v. the United Kingdom, Judgment of 8 February 1996, Reports 1996-I. 30.; Söylemez v. Turkey (Application no.46661/99) Judgment of 21 September 2006; Dayanan v. Turkey (Application no. 7377/03) Judgment of 13 October 2009 .

41 Bartkó-Bencze (2017) 27.

42 Cape et al. (2010) 36-44.
} 
lis (alaki) védekezésről, azaz amikor védő látja el a terhelt védelmét. Előbbivel (lásd 1.) kapcsolatban a bíróság részletes vizsgálat alá vonja (a) a védelem eljárási cselekményen való jelenléti jogát, valamint az ügyirat megismerésének kérdését; ${ }^{43}$ (b) a szabadlábon való védekezés jogát. ${ }^{44}$ Utóbbival (lásd 2.) kapcsolatban (a) a kirendelt és meghatalmazott védő büntetőeljárási helyzetével, egymáshoz való viszonyukkal; 45 (b) az ingyenes jogi képviselettel és a személyes költségmentességgel; ${ }^{46}$ (c) a fogvatartás jelentőségével; ${ }^{47}$ (d) a védőhöz való jogról lemondás ${ }^{48}$ kérdésével foglalkozik részletesen a bíróság.

Másfelől kiemelt kérdésként foglalkozik az EJEB „a védő számára az eljárásban biztosított hatékony részvétellel”. Így vizsgálja a 1. védelemhez való jog biztosítását, az állami hatóságok ezzel kapcsolatos felelősségét; ${ }^{49} 2$. a terhelt és védő közötti kellő idő biztosítását a konzultációra - e területen belül prioritásként kezeli azt, hogy (a) „Mikortól él a védőhöz és a védelemhez való jog a büntetőeljárásban?; (b) Milyen minimum garanciákat kell biztosítani a fogva lévő terhelttel való kapcsolatfelvétel esetén?"50 - 3. a terhelt és a védő közötti kapcsolattartás, kommunikációs bizalmasságával; ${ }^{51} 4$. az úgynevezett védői cselekvési szabadsággal. ${ }^{52} \mathrm{Az}$ utóbbival kapcsolatban - a magyar büntetőeljárásokban is kiemelt kérdésként kezelt - (a) védői magánnyomozás kérdésével, valamint (b) a védelem oldala által beszerzett magánszakértői vélemény sorsával.

Jelen tanulmányban a továbbiakban csak a kirendelt védői rendszerrel kapcsolatos alapkérdésekre térek ki.

43 Például: Lala v. Netherlands (Application no. 14861/89), Judgment of 22 September 1994; Kremzov v. Austria (12350/86) 21 September 1993; Belziuk v. Poland (23103/93) Judgment of 25 March 1998; Correia de Matos v. Portugalia (Application no. 48188/99) Judgmnet of 15 November 2001; Meftah and Others v. France (Application nos. 32911/96, 35237/97, 34595/97) Judgment of 26 July 2002; Beraru v. Romania (Application no. 40107/04) Judgment of 18 Marc 2014; Somogyi v. Italy (Application no. 67972/01) Judgment of 18 May 2004; Gregacevic v. Croatia (Application no. 58331/09) Judgment of 10 July 2012; Coniac v. Romania (Application no. 4941/07) Judgment of 6 October 2015.

44 Brennan v. United Kingdom (39846/98) Judgment of 16 October 2001.

45 Croissant v. Germany (Application no. 13611/88) Judgment of 25 September 1992. Az új magyar Be. e ponton kifejezett előrelépést mutat, a meghatalmazott védő és kirendelt védő közötti együttműködési kötelezettséget írja elő [Be. 48. § (4)-(6) bek.].

46 Pakelli v. Germany, Judgment of 25 April 1983, Series A no. 64., Mikhaylova v. Russia (Application no. 46998/08) Judgment of 19 November 2014.

47 Aleksandr Zaichenko v. Russia (Application no. 39660/02) Judgment of 18 February 2010.

48 Pakelli v. Germany (Application no: 8398/78), 25 April 1983; Panovits v. Cyprus (Application no. 4286/ 04) Judgment of 11 December 2008; Galstyan v. Armenia (Application no. 26986/03) Judgment of 15 November 2007; Pishchalnikov v. Russia (Application no. 7025/04) Judgment of 24 September 2009; Saranchov v. Ukraine (Application no. 2308/06) Judgment of 9 June 2016.

49 Kamasinski v. Austria (Application no. 9783/82) 19 December 1989.

50 Öcalan v. Turkey (Appkication no. 46221/99) Judgment of 12 May 2005; Bogumil v. Portugalia (Application no. 35228/03) Judgment of 7 October 2008; Sakhnovskiy v. Russia (Application no. 21272/03) Judgment of 2 November 2010.

51 E ponton ellentmondásos EJEB joggyakorlat mutatható ki, vö. Can v. Austria, Judgment of 30 September 1985, Series A no. 96; S. v. Swizterland, Judgment of 28 November 1991, Series A no. 220; Lanz v. Austria (Application no. 24430/94) Judgment of 31 Januray 2002; Öcalan v. Turkey (Application no. 46221/99) Judgment of 12 March 2003; Moroz v. Ukraine (Application no. 5187/07) Judgment of 2 March 2017.

52 Poitrimol v. France (Application no. 14032/88) Judgment of 23 November 1993. 


\section{A kirendelt védői rendszer}

A védelemmel kapcsolatos eljárási szabályok minősége jól tükrözi egy adott állam szintjén a jogállamiság elvének érvényesülését, „a védői jogállás szintje, elméleti és gyakorlati minősége a jogállamiság szeizmográfja is egyben”. ${ }^{53}$ Kifejezetten igaz ez az állítás a kirendelt védői rendszer múködésére.

Ahogyan arra az Artico v. Olaszország ügy kapcsán is rámutattam, a kirendelt védők büntetőeljárásba való bevonása esetén kifejezetten jelentkezik az igény a hatékony védelemre. A bíróság általánosságban rögzítette ezzel kapcsolatban, hogy egyezménysértéshez a kirendelt védők nagyobb hibái, teljes mulasztásai vezethetnek; ${ }^{54}$ a kisebb hibák, a „nem ügydöntő jelentőségű mulasztások” nem róhatók az érintett állam terhére. ${ }^{55} \mathrm{~A}$ bíróság határozataiban azt is világosan leszögezte, hogy az állam általában nem tehető felelőssé a kérelmező [terhelt] által meghatalmazott védő esetleges hibáiért vagy mulasztásai miatt. ${ }^{56}$

Hazánkban a kirendelések elosztása nem arányos és nem átlátható. ${ }^{57} \mathrm{E}$ körben az EJEB 2016-os döntésében megállapította, hogy a magyar állam megsértette a magyar Helsinki Bizottság véleménynyilvánításhoz füződő jogát, amikor a rendőrség megtagadta a kirendelt védők nevének és az általuk vitt ügyek számának kiadását a szervezet számára. ${ }^{58}$ Mindemellett több kutatás rámutatott arra, hogy a kirendelt védői rendszer Magyarországon nem nyújt hatékony védelmet. ${ }^{59}$ Ennek oka egyfelől az alacsony díjazás, másfelől pedig az, hogy „a védelmet a vád választja ki”, ${ }^{60} \mathrm{azaz}$ az, hogy a védő kirendelését és a kirendelt védő személyének a kijelölését az adott bűnügyi hatóság teszi meg. A kirendelés egyik legfőbb problémája tehát az, hogy a kirendelt védő személyének meghatározása ad hoc jellegű, lényegében a kirendelő szubjektív megítélésén alapul, ami önkényességhez is vezethet. ${ }^{61} \mathrm{~A}$ jogalkotó az új büntetőeljárási törvényben a díjazás rendezését nem vállalhatta magára, a kirendelt védői rendszer reformját csak anynyiban valósította meg, hogy úgynevezett osztott modellt vezetett be. Ennek lényege, hogy a kirendelést továbbra is az adott bünügyi hatóság teszi meg, ugyanakkor a kirendelt védő személyét külön jegyzékből az illetékes területi ügyvédi kamara jelöli ki (információs rendszer múködtetésével, valamint az azonnaliság elvének bevezetésével, amely utóbbi 1 órás határidőt biztosít a területi ügyvédi kamaráknak arra, hogy a kirendelő hatósággal a védő nevét és elérhetőségét közölje) [vö. Be. 46. § (1), (3) bek.].

\footnotetext{
Fenyvesi (2009) 6.

Sannino v. Italy (Application no. 30961) Judgment of 27 April 2006.

55 Kamasinski v. Austria, Judgment of 19 December 1989, Series A no. 168.

56 Vö. Grád-Weller (2011) 407.

57 Szabó (2017) 145.

58 A strasbourgi eljárás amiatt indult, hogy az adatszolgáltatást megtagadó rendőrkapitányságok esetében az akkori nevén Legfelsőbb Bíróság háromszor is úgy döntött, hogy a rendőrség által kirendelt, az állam által fizetett védők neve és az általuk vitt ügyek száma nem nyilvános adat, így azokat nem kell kiadni a szervezetnek. Magyar Helsinki Bizottság v. Hungary (Application no: 18030/11) Judgment of 8 November 2016.

59 Így „Az állampolgári jogok országgyưlési biztosának Jelentése az OBH 6564/1996. számú vizsgálatról”; „Az alapvető jogok biztosának jelentése az AJB-3107/2012. számú ügyben”.

60 Kádár et al. (2007) 20.

61 Védői jogok a bírósági eljárásban - Összefoglaló vélemény (2014) 22.
} 
E ponton érdemes kitérni arra a kérdésre, hogy visszaszállhat-e a kijelölés joga a bünügyi hatóságra. Az eljárási törvény a 47. §-ban rendelkezik erről a kérdésről úgy, hogy eközben reagál a joggyakorlatban felmerülő azon problémára, amely szerint tipikusan a nyomozási szakaszban történtek visszaélések a védő személyének kijelölését illetően. A 47. § ugyanis vádemelés előtti és utáni szakaszokra bontva rendelkezik arról, hogy mi történik azokban az esetekben, ha (a) nincs 1 órán belüli védő kijelölés; (b) a kijelölt védővel szemben a kijelöléskor kizáró ok állapírható meg; (c) vagy elérhetetlen a kijelölt védő, és az eljárási cselekmény végzése nem mellőzhető. Vádemelés előtt ezekben az esetekben a nyomozó hatóság vagy ügyészség gondoskodik a védő jelenlétéről az eljárási cselekményen, úgy, hogy az - (a) esetet kivéve - az eredetileg kijelölt személy védői státuszát nem érinti. ${ }^{62}$ Tehát ezekben az esetekben nem jelöl ki a nyomozó hatóság / ügyészség új védőt, helyette gondoskodik védő jelenlétéről a helyettes védőre vonatkozó szabályok alapján. Vádemelést követően azonban a nevesített esetekben [(a)-(c)] a bíróság kijelöli a kirendelt védőként eljáró ügyvédet. Azaz amíg nyomozási szakban nem engedi, addig a bírósági szakban már bizonyos esetekben visszaszállhat a kijelölés joga a bíróságra.

\section{Zárógondolatok}

„A védelem joga és lehetősége a kontradiktórius eljárásnak esszenciális fogalmi ismérve."63 Ugyanakkor a védelemhez való jog nem abszolút jog. Mind az EJEB, mind a hazai jog(gyakorlat) megengedi annak korlátozását.

A hatékony védelemhez való jog mind a hazai, mind a nemzetközi szakirodalom szerint a büntetőeljárások egyik legfontosabb alapelvének minősül. Az alapelvek (így a védelemhez való jog is) mindig értékeket közvetítenek, amelyek azonban nem csupán az eljárás rendszerére, hanem azon túl az eljárás müködésének, valamint az érintettek jogainak legfontosabb vonásaira is vonatkoznak. ${ }^{64}$

Jelen tanulmány keretében célom a hatékony védelemhez való jog EJEB joggyakorlatán keresztül történő bemutatása volt, rávilágítva arra, hogy maga a bírósági gyakorlat sem feltétlen következetes (így például hullámzó joggyakorlat mutatható ki abban, hogy a védelemhez való jogot az egyezmény 6. cikk 1. bekezdésével együttolvasva vagy önállóan lehet értelmezni); ugyanakkor olyan alapvető zsinórmértéket állít fel, amelyeket a magyar büntetőeljárásokban is meg kell fontolni. Egyik ilyen terület a kirendelt védőkkel kapcsolatos olyan szabályozás (kirendelési és kijelölési struktúra kiépítése, jogok és kötelezettségek deklarálása) kialakítása, amely megteremti annak az alapját, hogy a védelem tényleges és hatékony legyen a terhelt számára.

\footnotetext{
Bánáti (2018) 117.

Király (1962) 77.

4 Erdei (2011) 141.
} 


\section{IRODALOMJEGYZÉK}

Balogh Jenő (1901): Magyar bünvádi eljárási jog. Budapest, Grill Károly Cs. és kir. udvari könyvkereskedése.

Bánáti János (2018): A védő. In Belovics Ervin - Erdei Árpád szerk.: A büntetőeljárási törvény magyarázata. Budapest, HVG-ORAC.

Bartkó Róbert - Bencze Krisztina (2017): A hatékony védelemhez való jog az új Büntetőeljárási törvény tervezete tükrében. Jog - Állam - Politika, 9. évf. 2. sz. 25-38.

Cape, Ed - Namoradze, Zaza - Smith, Roger - Spronken, Taru (2010): Effective Criminal Defence in Europe. Antwerp-Oxford-Portland, Intersentia.

Elek Balázs (2015): A kényszerintézkedésekhez kapcsolódó iratmegismerési jog a nyomozás során. In Elek Balázs - Fázsi László szerk.: Az ítélőmesterség dilemmái - Tanulmányok Dr. Remes Zoltán bíró emlékére. Debrecen, Printart-Press.

Erdei Árpád (2011): Tanok és tévtanok a büntetöeljárás tudományában. Budapest, ELTE Eötvös Kiadó.

Erdei Árpád (2018): Preambulum. In Belovics Ervin - Erdei Árpád szerk.: A büntetőeljárási törvény magyarázata. Budapest, HVG-ORAC.

Fenyvesi Csaba (2009): A bünügyi védő perjogi helyzete a magyar büntetőeljárás keretében. Ügyvédek Lapja, 4. sz.

Gácsi Anett Erzsébet (2017a): Elmélkedések a fegyverek egyenlőségének elvéről. In Gellén Klára szerk.: Honori et Virtuti. Ünnepi tanulmányok Bobvos Pál 65. születésnapjára. Szeged, Iurisperitus Kiadó.

Gácsi Anett Erzsébet (2017b): A fegyverek egyenlőségének elve az Emberi Jogok Európai Bíróságának joggyakorlatában. Belügyi Szemle, 65. évf. 9. sz. 5-23.

Grád András - Weller Mónika (2011): A strasbourgi emberi jogi bíráskodás kézikönyve. Budapest, HVG -ORAC.

Kádár András Kristóf - Kirs Eszter - Lukovics Adél - Moldova Zsófia - M. Tóth Balázs (2014): Az Emberi Jogok Európai Bíróságának elózetes letartóztatással kapcsolatos gyakorlata. Kézikönyv bírák számára. Budapest, Magyar Helsinki Bizottság.

Kádár András Kristóf - Tóth Balázs - Vavró István (2007): Védtelenül - javaslat a magyar kirendelt védői rendszer reformjára. Budapest, Magyar Helsinki Bizottság.

Kézikönyv a büntetöeljárások terheltjeinek védőhöz és költségmentességhez való jogáról (2018). Magyar Helsinki Bizottság.

Király Tibor (1962): A védelem és a védô a büntetôügyekben. Budapest, KJK.

Kovács Kriszta (2013): Az emberi jogok európai egyezménye és az uniós jog szerepe az alapjogi ítélkezésben. In Somody Bernadette szerk.: Alapjogi biráskodás - Alapjogok az itélkezésben. Budapest, L'Harmattan.

Lemmens, Paul (2014): The right to a fair trial and its multiple manifestations. In Brems, Eva - Gerards, Janneke ed.: Shaping Rights in the ECHR. Cambridge, Cambridge University Press.

Reid, Karen (2015): A Practitioner's Guide to the European Convention on Human Rights. London, Sweet\&Maxwell.

Róth Erika (2016): A tájékoztatáshoz való jog. In Róth Erika szerk.: Decem anni in Europaea Unione V. Miskolc, Miskolci Egyetemi Kiadó.

Szabó Krisztián (2016): Iratismeret az előzetes letartóztatással kapcsolatban - eltérő jogalkalmazási tapasztalatok. Magyar Jog, 63. évf. 3. sz. 183-188.

Szabó Krisztián (2017): Az Emberi Jogok Európai Bírósága ítélkezési gyakorlatának hatása a magyar büntetőeljárási törvényre. Pro Futuro, 6. évf. 1. sz. 128-150.

Uitz Renáta (2016): Nemzetközi emberi jogok és a magyar jogrend. In Jakab András - Gajduschek György szerk.: A magyar jogrendszer állapota. Budapest, MTA TK JTI. 


\section{Jogforrások}

A 2017. évi XC. törvény indokolása (a büntetőeljárásról).

Védői jogok a bírósági eljárásban. Összefoglaló vélemény (2014). Kúria Büntető Kollégium - Joggyakorlat-elemző csoport. 2014.EL.II.E.1/10.VÉDÖ-50. sz.

\section{ABSTRACT \\ The Right to Effective Defence in the Legal Practices of the European Court of Human Rights}

GÁCSI Anett Erzsébet

Whether categorized in a broader or a narrower sense, the principle of equality of arms is an essential element of the right to a fair trial and serves as a guarantee in criminal proceedings that the defence side (consisting of the defendant and the defence counsel) has such rights whose weights are comparable to the charge filed against the defendant. The right to defence (known as the 'right to effective defence' in the legal practices of the European Court of Human Rights, in the acts on criminal proceedings being effective in several foreign countries as well as in the new Hungarian Act on Criminal Proceedings) is a nominated element of the right to a fair trial and, in a broader sense, is also an element of the principle of equality of arms (in a narrower sense, the right to defence falls out of the scope of the principle of equality of arms but shares multiple points of connection with it). In my study, I present the substance of the right to effective defence through the legal practices of the European Court of Human Rights.

Keywords: principles, right to a fair trial, right to effective defence, the principle of equality of arms 